\title{
POTENTIAL USES AND ROLE OF CROP RESIDUES IN AGRICULTURE
}

\author{
NISHA $^{* 1}$, DINESH CHANDRA ${ }^{2}$, ROHIT KUMAR ${ }^{3} \&$ P. B. RAO ${ }^{4}$ \\ ${ }^{1}$ Goverment P. G. College Syalde Almora, Uttarakhand, India \\ ${ }^{2,}$ Goverment Inter College Almora, Uttarakhand, India \\ ${ }^{3}$ Department of Civil Engineering, G.B. Pant University of Agriculture and Technology, Uttarakhand, India \\ ${ }^{4}$ Department of Biological Sciences, G.B. Pant University of Agriculture and Technology, Uttarakhand, India
}

\begin{abstract}
The rapidly changing environmental and economic needs of society are putting ever increasing pressures on the forest industry "do more with less". In practical terms, it means, increasing conversion and more effective use of crops residue acts as resources improving the scenario of crop system, and also playsthe role as environment friendly products. It helps different technologies, which consider use of non-timber ligno-cellulosic residues for industrial product. In this regard, crop residue are more environmentally friendly technologies for turning agricultural waste like wheat rice and straw, coconut, bamboo, husk, jute, coir, sugarcane bagasse, casuarinas leaves, pine needle, cotton stalk and stem of banana etc. Here, we have summarized information regarding the different uses of crop residues available in literature.
\end{abstract}

KEY WORDS: Crop Residues; Bio Fuel; Soil Health \&Environment Effects

Received: Feb 08, 2019; Accepted: Mar 01, 2019; Published: Jul 06, 2020; Paper Id.: IJBRDEC20201

\section{INTRODUCTION}

Crop residues are waste product obtained from different parts of crop plant such as, stem, leaves stalks, husk and shell etc. Their use varies across many different states and regions of our country. Crop residues defined as; any part of plant that remain in field after harvesting, it varying greatly by having different properties rate time period of decomposition (Al-Kaisi and Guzman, 2011). Traditionally, crop residue composed of wasteful material such as, feed for animals, fuel, fodder, packaging, composting and roof thatching. The residue coming from cereal crops mainly use for feeding cattle's in household. Rice straws and husk one of first and foremost examples of residues used for domestic fuel is used for parboiling process of rice. In many states and countries, farmers use crop residue either for themselves, or they sell it land less house-holds, to intermediaries which can further sold them in different industries while remaining residue left unused or it burnt in farm. In Indian, states of Haryana and Punjab, crop residues coming from rice crop not used in feeding cattle due to this; its large amounts is burnt by farmers. Sugarcane, a well-known example of ratoon crop tops either used to feed of milk or dairy animals, and sometime it is also burnt in most parts of the country. The outer shells of groundnuts are treated as residues and are used as fuel in bricks and lime kilns. The residue of many other crops such as of chilli, cotton, legumes and oil-seed crops are mostly used as fuel for house hold need. While exocarp of rapeseed, coconut and mustard stalks, jute, pigeon pea, mesta and sunflower were used in domestic fuel.

In many developing countries, residues of many crops were used for energy productions, and it has been reported that these are important source of energy, in the traditional form residues are used to fulfil to meet the demands ofdomestic uses (Baker et al. 2014). In industrialized parts of many countries, crop residues are also used 
in energy production and it has considered a substitute of fossil fuel. Resources obtained or provided by nature are categorised into two renewable and non-renewable. Energy sources, which have a great importance in each and every field also is a basic need of daily life; an example of non-renewable source, means once it is exploited, it cannot be regain quickly; fossil fuel, coal and petroleum are such an example. To overcome this scarcity, CR plays very important and significant role and secure a special position to overcome need to fossil fuel in some extent. Burning of fuel has a detrimental consequence on environment resulting from of greenhouse gases, in this context; CR can be substitute or play a role of renowned energy source. The gradual changes occur in energy mix, replace fossil fuel for renewable sources of energy, one of the foremost ways for mitigation of greenhouse gas and their detrimental effects on global warming. Thus significant rise is expected on production of bio-energy in upcoming or near future, to attend growing global demands (IRENA, 2016). In this scenario, stake holders in this sector increase their interest $\&$ investments for CR as a raw material, used for bio-energy production, mainly from cellulosic ethanol, which is regarded as second-generation ethanol (E2G) and bio-electricity (Bentison et al. 2014; Bivjoy and Vashistha,2003).

In current scenario, most crop residue was remaining left in field after harvesting; it is considered as under used for production of energy. Moreover, crop residues play important role amendment of soil properties, which include physiochemical and biological by diversifying microorganism. It also improves the other environmental services (Blanco and Lal, 2003; Campos et al. 2010; Campos et al. 2013; Carvello et al. 2017; Chan et al. 2008). Therefore, since usage of crop residues for production of energy is very promising way on global scale, trade-offs and environment synergism, which is associated much with crop residue management that cannot be overlooked. While understanding complexity on this subject, research has carried out in understanding mechanisms and other isolated processes, an attempt has been made to summarize and integrate this very important knowledge (Davies et al. 2012), which may support other researchers and other persons, related within bio-energy sector [figure 1]. Thus, review of any particular knowledge is basically a collection and accumulation of facts. In this regard, present study is for synthesing, and discussing various aspects of information available in literature on potential impacts and uses of crops residue on soil health, greenhouse gas emissions, as well as on its effect on plants growth development and its yield in areas for bio-energy purposes.

\section{CROP RESIDUES}

\subsection{Crop Residues Availability}

Our biosphere is blessed with diversity or the variability which makes it unique at each places of world in its variety of flora, fauna supported by different environmental conditions. So, there is large variability also seen in crops residue uses and its generation in different regions or parts of country depending on cropping system its intensity, production yields and crops grown, recoverable biomass quantity from grassland, cropland, forest, roadsides and agro-forestry (Franzluebbers, 2015). That estimated available crops residue in India is approximately 523.4 MT/year its surplus is almost 127.3 MT/year. Annual surplus crops residue in cotton and pigeon pea stalk(11.8), jute (9.0) and mesta (1.5), shell of groundnut (5.0), rapeseed, mustard (4.5) and sunflower (1.0 Mt/year) respectively. Residues of most cereals crop is approximately $50 \%$ of pulses are used for fodder purposes and coconut, rape seed, pigeon pea, mesta, jute, sun flower and mustard are used for domestic fuel. SPRERI (2004) gave an estimate for crops residue burnt (71.6 Mt) in some India states listed (Table 1). The $40 \%$ to $50 \%$ of mustard and cotton stalks show availability as a surplus out their total stalk generation (29.4 - 9.4 MT) respectively [table 1]. 


\subsection{Crop Residues as Energy Source}

Energy is the basic need for sustaining life in any system, it is also important to do or to perform any kind functioning, so energy is extracted from biomass. Biomass is used as a source of energy, which is very interesting worldwide, because of its various environmental advantages. During recent decade, it is used for energy production and has been proposed interestingly and increasing used as a substitute for non-renewable sources of fossil fuels. It also offers an immediate solution for reduction of $\mathrm{CO}_{2}$ content in atmosphere (Gemtos and Tsiricoglowe, 1999). It has two important advantages: firstly and fore mostly, it is a renewable source and secondly, it used without any damage to environment (Guzman et al. 2015). In addition, positive global effects in comparison with other energy sources, it represents very low or almost no risk. When comparison with renewable energy resources such as wind, solar biomass which are storable resources, it is cost effective and inexpensive with many other favourable efficiencies in terms of energetic. Some common and important crops residues are discussed below.

\subsubsection{Rice}

Among all agricultural residues, most abundantly and commonly available is paddy husk. It is by-product of most important agro- based industries in different parts of country, namely paddy milling. Paddy husk is available to the extent of $2 \mathrm{MT} /$ annum. Major constituent of husk: Cellulose (a polymer of glucose) is $28 \%$; pentosan - (polymer of pentoses and hexoses) $26 \%$; Silica - $15-22 \%$. It's important to note the structure of siliceous and organic component, in association throughout the husk. Manufacture of boards is done by admixture of a suitable binding agents, and is of undoubtedly best known method, from the point of view of both value added and complete utilization of husk without any further secondary by products [Figure 2]

\subsubsection{Wheat}

Wheat is a major cereal crop, and is extensively grown in northern part of India. The estimated production, approximately in 1995-96 was 70 MT. It is used for livestock and also in bio ethanol production.

\subsubsection{Groundnut}

It is well known and coming under oils seed crop. The largest production of groundnut crop in India is in the area of about 8.5 M.H, with an annual production, approximately 6.6 MT. Assuming that on average 4 tonnes of its yield gives one tonne husk, availability of residue is almost 1.7 million tonnes per annum. At present, it is a valuable resource and is burnt as fuel in lime and brick kilns also, in decorticating nut factories. Also, it is reported to be used as domestic fuel for parboiling of rice, water heating and functions as separators in packaging. Although techno economic feasibility of particle board production from this material was established in India far back as 1970, this technology has not been commercialized. In view of this, it is in large and abundance, come forward as a very promising material (Hammerback et al. 2012).

\subsubsection{Sugarcane}

Sugar is obtained from cane in $65-70 \%$ of world production. The production is mainly confined to developing countries, however, Cuba and Brazil are known as "World sugar bowl". A major residue of sugar production is filter cake. Residue from cane juice is coming from filtration. The wastage or a left product is known as filter cake or bagasse, and used as fuel at sugar mill. Filter cake, sometimes is used as fertilizer for improving soil, which is directly applied on fields after composting. Bagasse is fibrous, left after juice extraction. Fibre content ranges from 26-30 to 33-36\%. It is often used as 
primary fuel for sugar factories, when burnt in large quantity; it produces sufficient energy in the form of heat supply and all needs of typical sugar mill, including energy to spare. Secondary use of this product is in cogeneration, fuel is used to provide heat and energy in mill and also electricity, which is typically sold to consumer electricity grid. It is also used in cattle feed when mixed with molasses.

\subsubsection{Sugar Beet}

Sugar beet has onlyhalf of capacity for adding humified organic carbon to soil, in comparison to cereal crops. This is due to the large harvest index and large root to shoot ratio, leaves less residue on field as compared to cereals. For sugar beet production, it is an option of shoot incorporated into soil, compared to combination of root shoot harvesting. Although it has a great potential, adding organic matter into soil is lower in comparison to cereal crop residue. Root shoot harvesting leaves less organic matter, after cultivation.

\subsubsection{Biochar}

Biochar is produced via burning of wastage biomass at $300-600{ }^{\circ} \mathrm{C}$, in partial or complete exclusion or absence of oxygen, this process is also known as pyrolysis. Due to relatively stable bio-logical state of biochar, it is produced for application on soil, proposed way of diverting waste bio-mass as carbon source from a rapid to slow carbon-cycle pool present in soil. In recent years, over use of chemical fertilizer leads to damage of soil quality and increased the concern for healthy production of food, and also better environment increases emphasis to sustain higher productive capacity of soil, raised interests for maintenance, improvement of soil organic matter by adopting appropriate use of land and better management practices (Jang et al. 2015; Jin et al. 2014). Interest towards using synthetic biochar in past few years, has been an amendment, worldwide. Treatment of soil by synthetic biochar may provide novel soil management practice; due to its potential to improve enhance soil carbon, soil fertility. Also, use of biochar lead to mitigation of greenhouse gas emissions, reduce nutrients leaching and chemicals, and thus increase fertiliser use efficiency, along with enhance agricultural productivity (Karraka et al. 2014; Lal, 2009). Enormous quantities of crop residues obtained from rice straw, rice husk and other surplus residues are available in the North West region ofIndia that could potentially be pyrolysed for production of bio-energy, thereby reducing field burning. Also, as a biochar by-product it could help to improve soil health, avoid methane emissions, and work as carbon sequester. However, if massive residues export is possible without any compensation, this could result in an improved and eroded soil, which can further lower food crops [figure 3].

\section{IMPACT OF CROPS RESIDUE}

Soil Health: Soils with low organic matter content is consistently depleted in their finite reserve of nutrient, by the up taking of crop. Excessive nutrient mining from soil is a major cause of soil fatigue. The nutrients' quantities removed by rice, wheat are more than the amount added through various fertilizers. Straw Removal from crop fields lead to potassium mining at an alarming rate because, $80-85 \%$ of potassium is absorbedthrough rice and wheat crop remains in straw form (Lahmann, 2006). The long term sustainability depends upon input and outputs of carbon, and carbon-use efficiency. Practices that enhance organic matter to soil through exogenous supply and also on-farm recycle activities improve crop productivity and soil fertility. There are many benefits of residue retention in crop land, especially if it is maintained as surface mulch combined with direct seeding of crops, without 'normal' tillage. Incorporation of crops residue also improves soil fertility status, judged by organic matter and available phosphorous and potassium contents (Liska et al. 2014). 
Pests: Addition of crop residues on agriculture fields affect pest directly and indirectly. It alters the egg laying in cut worms and beetles. Low soil temperature and high moisture content under crop resides, effect pest infestation, it goes to affect indirectly the types and density of weeds, influence insect and its natural enemies. However, it increases arthropods diversity, which help in reducing the pressure developed on pest. Surface residues ensure survival of beneficial and harmful insects. It has been seen that reduction in tillage system under staggered planting system of monoculture crop, contains higher level of pest inoculums than conventional system. Decomposition of crop residue along with several inter related factors like crop geometry, climate, irrigation, cultural practice and pesticide may affect survival rate of insect in crop residue.

\section{BENEFITS OF RESIDUES OBTAINED BY CROPS}

\section{A. Other Benefits:}

- Increase productivity of soil, so directly increaseyield

- Maintain organic matter content in soil

- Modify soil structure

- Control soil depletion by buffering soil against forces of raindrop impact and wind shear

- Increases infiltration rates of water

- $\quad$ Retain soil moistures

- Recycle plant nutrients

- Function as an habitat and source of energy for microorganism

\section{B. Environmental Benefits}

- Mitigate flooding by holding water, and control it from being run off

- $\quad$ Reduce surface run off and decrease sedimentation

- Improve water quality by acting as a filtrate to pollutant and denature them

- $\quad$ Reduce other sources of pollution

- Minimize risks of anoxia and dead zones in coastal ecosystem

\section{APPALS OF CROP RESIDUES ON GREENHOUSEGASES}

Till today, there is no consensus on exact or real impact of residue harvest on emissions of greenhouse gas. Studies claim that harvests of crop residue stimulate their emissions (Mars, 1970; Mendham et al. 2003) 1, 22]. On other hand, it also indicates that residues harvest management does not alter emission or even reduce emissions from soil (Nendel et al. 1998; Pimentel et al. 2015). Many other diverse factors affects directly or indirectly in production and emission of gas, contributing to variability of result found in literature (Pittelkow et al. 2013; Pourhasham et al. 2013; Prasad et al. 2013 and Puget and Lal, 2005). These factors could be environmental in origin, edaphic and related to quantity and quality of material use to cover soil (Rocha et al. 2005). 
In general, largest greenhouse gases emission is found when a huge amount of material is left on soil surface (Sahrawat et al. 2012; Signor et al. 2014), observe decrease in emissions of two to three times under total straw harvest, compared to $14 \mathrm{Mg}$ ha-1 or $21 \mathrm{Mg}$ ha-1 of sugarcane straw, left on crop land. A similar trend was observed under total maize harvest, compared to no harvest. Generally, an increase in soil $\mathrm{CO}_{2}$ emissions is observed with maintenance of crop residues in field (Six et al. 2014). Maize harvest decreased soil's total $\mathrm{CO}_{2}$. However, $\mathrm{CO}_{2}$ from decomposed residues cannot be counted on studies that produce inventories of greenhouse gases emission in agriculture; the main reason behind this $\mathrm{CO}_{2}$ isbiogenic cycled in soil-plant-atmosphere, distinguished from $\mathrm{CO}_{2}$, emitted from fossil fuel used for production energy, which accumulates in atmosphere (Stavi et al. 2016). Nevertheless, crops residue harvest could favour $\mathrm{CO}_{2}$ emissions, due to temperature increase and moisture reduction in soil. The harvest of crop residues over years should reduce organic $\mathrm{C}$ in soil that could cause significant implications for $\mathrm{CO}_{2}$ emissions (Tavares et al. 2010). Burning of residue led to release of soot particle and its smoke cause human and animal health problem. It also leads to emission of greenhouse gas namely methane, carbon dioxide and nitrous oxide, cause global warming and loss of plant nutrient like $\mathrm{N}$, $\mathrm{K}, \mathrm{P}$ and $\mathrm{S}$. Burning of crop residue is a complete waste of an important resource that could be a source of bio-active, carbon compound, feed and energy for rural house-holds and small industries. Heat generated after residue burning increases soil temperature, which causes death of beneficial microorganism, though it is a temporary phenomenon, as microbe can regenerate after a few days. But repeated burning in field can diminish, permanently. The burning of crop residue immediately increases exchangeable $\mathrm{NH}^{+}-\mathrm{N}$ and bicarbonate- extractable $\mathrm{P}$ content, there is no build-up of nutrient in profile. Long-term burning reduces total nitrogen and carbon, potentially mineralizable nitrogen in upper soil layer. Burning of agricultural residues led to significant emissions of relatively important gases, such as carbon monoxide (CO), methane $\left(\mathrm{CH}_{4}\right)$, nitrous oxide, oxides of sulphur $\left(\mathrm{SO}_{\mathrm{X}}\right)$, nitrogen $\left(\mathrm{NO}_{\mathrm{X}}\right)$ and other hydrocarbons into atmosphere. Approximately, $70 \%$ to $7 \%-0.7 \%$ of carbon is present in rice straw emitted as methane, carbon dioxide, carbon monoxide respectively, while $2 \%$ of $\mathrm{N}$ in straw is nitrous oxide, upon burning. Also, emit a large amount of particulate that consist of wide variety of inorganic and organic species. It has been seen that one ton rice straw on burning goes to release particulate matters $(3 \mathrm{~kg}), \mathrm{CO}_{2}(1460 \mathrm{~kg}), \mathrm{CO}(60 \mathrm{~kg}), \mathrm{SO}_{2}(2 \mathrm{~kg})$ andash $(199 \mathrm{~kg})$. Besides, some other light hydrocarbon, and semi volatile organic compounds (SVOCs), volatile organic compounds include polychlorinated biphenyls, polycyclic aromatic hydrocarbons, NOx and SOx are also emitted. These gases are major concern for their role in global impact and lead to increase in levels of acid deposition, aerosols and their relative concentration increase in troposphere, ultimately lead to depletion of ozone in stratosphere. These, subsequently undergo trans-boundary migration depending upon wind speed or direction, reaction with oxidant like $\mathrm{OH}$ led to physico-chemical transformation, eventually washing out in precipitation. Many pollutants found in larger quantity in "biomass smoke", and are known or suspected carcinogenic agent thus, could be a major reason of various air-borne, lung and respiratory diseases [table 2].

\section{CROP RESIDUE'S ROLE IN PLANT GROWTH AND PRODUCTION}

The management of crop residues have many direct and indirect effects on yield of crops (Tomena et al. 2016). Tropical areas have different responses towards plants for maintenance of sugarcane straw on the soil. Surface of soil tilling and population of plants can be improved if maintained by straws, which increase stalk yield in relation to areas with straw burning (Trivelin et al. 2013). Tilling, growth and productivity of plants at end of cycle when all straw was left on soil surface, can be reduced conversely, as reported by [Valim et al. 2016]. Forest residue harvest or the waste product, coming from forest flora used for bio-energy production attain concern about potential negative long term effect on soil quality and timber productivity. It has been shown that, forest residues retain its help in increasing nutritional status and good 
productivity in eucalyptus trees [39, 40, 41]. If there is a complete removal of forest residues, it will result in decreased timber production by $40 \%$ in first and $6 \%$ in second cropping time, or second rotation of eucalyptus. On other hand, the condition in boreal forests, residue harvesting not play any significant role and not affectgrowth or production of timbers (Whiteboard et al. 2003). Harvesting of residue from the forest plantations can reduce soil fertility, and also cause reduction by $37 \%$ in growth of trees in subsequent cultivations, as reported by a global Meta data analysis [figure 4].

\section{MANAGEMENT OF CROP RESIDUES}

For the management and proper use of various residues coming from crop, for the improvement of soil fertility, and also for energy production in a cost effective way, proper strategies are required for recycling of residue. In this context, waste of ricecrop poses more problems to succeeding in comparison to wheat, because of shorter time period between rice residue incorporation and sowing period of wheat, rice residue, which generally have a slow decomposition rate due to high silica content and lower temperature. Therefore, a proper management plan for crop residues with effective and sustainable agriculture conservation is a vital process in long-term sustainability in agriculture scenario, in India. Hence, residues burning should be discouraged and utilized gainfully for a better conservation of agriculture, and improving soil texture and health quality, which also help in reducing environmental pollution. Those parts of countries, where crop residue used for basically to feed animals and some other useful purpose, in view of this, an adequate amount of residue should be recycled into soil. Many technologies are available to efficiently use crop residues in agriculture conservation. However, they may require substantial improvement for large sale adoption by resource.

\section{CROP RESIDUE UTILIZATION}

- To develop region specific crop residue inventories, including total production from crops, their utilization, quality and amount which burnt on farm, and to evolve management strategies. Usage of images produced by satellite can be used for estimation to quantify the residues burnt on farm.

- Qualitative assessment of various crops and their residues for suitability in off farm usage, like composting, animal feed, energy, bio-char, biogas and bio-fuel production on farm purposes.

\section{BASIC STRATEGIC MODEL}

- It is necessary to develop and introduce new varieties of crop, for production of more roots and shoot biomass for improving and nurturing natural resource of soil.

- To developsimulation model,this can be used for prediction of impacts involved in agriculture conservation for more crop growth, good crop yield, improved soil properties and more farm income.

- $\quad$ To enhance decomposition rate for residues, by in-situ incorporation.

- To design experiment study impact of conservation of agriculture, including soil health, nutrient, water use availability and efficiency, carbon sequestration, greenhouse gases emission and other ecosystem service for new generation.

- For the conservation of agriculture assessing of life cycle, including residue based conventional methods of disposing of crop residue, by either burning or other competing use. 


\section{OPTIMUM USES OF DIFFERENT CROPS RESIDUE}

- For analysing benefits, socio-economic, cost impact and technical feasibility in off and on-farm use of crop residue.

- Optimizing residue use that can be retained for agriculture conservation, without affecting crops livestock system, particularly the region where residues are the main sources of food and fodder.

- Assessing suitability of residues retention and incorporation in different climatic and soil situation.

- To quantify permissible amount of different crop residues, which can incorporate and retained, depending on a particular cropping systems, characteristics of soil, climatic conditions without creating any operational problem for upcoming or next crops, or any other kind of chemical and biological imbalance.

- Assessing benefits to the cost impact of environment on retention of residues, and also incorporation in agriculture conservation, burning of residue for shorter and longer term scales.

\section{MANAGEMENT OF NUTRIENT}

- Complete package should be developed involving different practices adopted in conservation of agriculture, for a prominent and promising crop system, in each and every agro-ecological region, particularly in rain fed dry land eco-systems.

- A need for proper scheduling of irrigation for conservation agriculture field, such as with surface carpet residue, anchored residues and like no residues.

- Developing different soil test methods, their recommendations of different fertilizer and also customized use of particular fertilizer for conserving agriculture that should be taking into account, the requirement of micro (trace) and macro nutrient required in cropping system.

- Assessing role of residues from legumes in sustainable maintenance of Carbon: Nitrogen: Phosphorous: Sulphur in soil.

\section{PEST MANAGEMENT}

- Developing practices package for (IPM) integrated pest management involves crop, tillage, residue, modified planting method and pesticides in agriculture conservation, to reduce pesticide use and minimize production and environmental pollution.

- Evaluation of weeds dynamic (shift and virulence weed floral biology) their interference potential and suitable managing practices with low-cost and environment-friendly herbicides in crop residues, in the conservation agriculture.

- Need of different technologies should be developed for controlling termite, in order to enhance crop yields and values of residue, left on surface during long interval time span between two successive crops.

\section{FARM MACHINERY}

- Development of appropriate machinery used for farming is for facilitation, reduction, collection, volume, 
transportation and application of crops residue, and sowing of succeeding crop under different layer of residues in soil surface.

- Modification and combination of harvester for collection and removal of crops residue from fields. Twin cutter bar combination harvester is involved in harvesting of top crop portion, for maximum recovery of grain process, and low bar cutter can be used for straw harvesting from a suitable height, also windrowing should adopted and can be developed for proper straw management.

\section{CONCLUSIONS}

As consequence of industrialization, there is change in the concept on environment,the standard of living is increasing,and the type of product required by people have changed considerably. In the past, wood was used as raw material for making many of our personal and domestic needs. The concept of environment protection has necessitated the stoppage of cutting trees in forest, and thus utilization of wood has been curtailed by manifolds. New environment friendly technologies for turning residue from agriculture waste into a quality based value added products using conventional formaldehyde based resins,have been developed. Implementation of new technologies will result in waste materials (agric-waste), being efficiently utilized as sustainable resource for industrial manufacture, reducing the amount of agricultural waste material and eliminating pollution, caused by burning of such residues.

\section{ABBREVIATIONS}

CR: Crop residues; E2G: Second generation ethanol; IRENA:The International Renewable Energy Agency; MT: Million tonnes; SPRERI: Sardar patel renewable energy research institute

\section{REFERENCES}

1. Al-Kaisi M, Guzman J (2012) Effects of maize residue removal on soil quality and greenhouse gas emissions in Iowa. Agrociencia 16(3):20-28.

2. Baker JM, Fassbinder J, Lamb JA (2014) the impact of corn stover removal on $\mathrm{N}_{2} \mathrm{O}$ emission and soil respiration: An investigation with automated chambers. Bioenerg Res 7(2):503-508.

3. Bentsen NS, Larsen S, Felby C (2014) $\mathrm{CO}_{2}$ emissions from crop residue-derived biofuels. Nat Clim Change 4:932.

4. Bijay SYS, Vashishta M (2003) Potassium nutrition of rice-wheat cropping system in the Indo-gangetic plains. Nutrient management for sustainable rice-wheat cropping system. Natl Agric Tech Project, Indian Counc. Agric Res New Delhi, India and Punjab Agric. Univ., Ludhiana, Punjab, India, 161-186.

5. Biswal, Sonali, and Manasi Ray. "Fermentation of Agro-Based Waste and Residues from Different Sectors: A Review. "International Journal of Agricultural Science and Research (IJASR) 7. 2, Apr 2017, 425-432

6. Blanco-Canquim H, Lal R (2009) Crop residue removal impacts on soil productivity and environmental quality. CRC Crit Rev Plant Sci 28(3):139-163.

7. Campos LHFD, Carvalho SJPD, Christoffoleti PJ, Fortes C, Silva JSD (2010) Straw management systems influence biomass accumulation and yield of sugarcane crop (var. RB855453). Acta Sci Agron 32(2):345-350.

8. Carmo JBD, Filoso S, Zotelli LC, de Sousa Neto ER, Pitombo LM, Duarte $\square$ Neto, PJ, Cantarella H (2013) Infield greenhouse gas emissions from sugarcane soils in Brazil: effects from synthetic and organic fertilizer application and crop trash accumulation. GCB Bioenergy 5(3):267-280. 
9. Carvalho JLN, Nogueirol RC, Menandro LMS, Bordonal RDO, Borges CD, Cantarella H, Franco HCJ (2017) Agronomic and environmental implications of sugarcane straw removal: a major review. Gcb Bioenergy 9(7):1181-1195.

10. Chan KY, Van Z L, Meszaros I, Downie A, Joseph $S$ (2008) Agronomic values of green waste biochar as a soil amendment. Soil Res 45(8):629-634.

11. Davis SC, PartonWJ, Grosso SJD, Keough C, Marx E, Adler PR, DeLucia EH (2012) Impact of second $\square$ generation biofuel agriculture on greenhouse $\square$ gas emissions in the corn $\square$ growing regions of the US. Front Ecol Environ 10(2):69-74.

12. Franzluebbers AJ (2015) Farming strategies to fuel bioenergy demands and facilitate essential soil services. Geoderma 259:251-258.

13. Gemtos TA, Tsiricoglou T (1999) Harvesting of cotton residue for energy production. Chim Astron 16(1):51-59.

14. Guzman J, Al-Kaisi M, Parkin T (2015) Greenhouse gas emissions dynamics as influenced by corn residue removal in continuous corn system. Soil Sci Soc Am J 79(2): 612-625.

15. Hammerbeck AL, Stetson SJ, Osborne SL, Schumacher TE, Pikul JL (2012). Corn residue removal impact on soil aggregates in a no-till corn/soybean rotation. Soil Sci Soc Am J 76(4):1390-1398.

16. Jang W, Keyes CR, Page DD (2015) Impact of biomass harvesting on forest soil productivity in the northern Rocky Mountains. RMRS-GTR-341. Fort Collins, CO: US Department of Agriculture, Forest Service, Rocky Mountain Research Station. 35 p., 341.

17. Jin VL, Baker JM, Johnson JMF, Karlen DL, Lehman RM, Osborne SL, Schmer MR (2014) Soil greenhouse gas emissions in response to corn stover removal and tillage management across the US Corn Belt. Bioenergy Res 7(2):517-527.

18. Kaarakka L, Tamminen P, Saarsalmi A, Kukkola M, Helmisaari H S, Burton A J (2014) Effects of repeated whole-tree harvesting on soil properties and tree growth in a Norway spruce (Piceaabies (L.) Karst.) Stand.Forest Ecol Manag 313:180187.

19. Lal $R$ (2005) World crop residues production and implications of its use as a biofuel. Environ Int 31(4):575-584.

20. Lal R (2009) Soil quality impacts of residue removal for bioethanol production. Soil Tillage Res 102(2):233-241.

21. Lehmann J, Rondon M (2006) Bio-char soil management on highly weathered soils in the humid tropics. Biological approaches to sustainable soil systems 113(517):e530.

22. Liska AJ, Yang H, Milner M, Goddard S, Blanco-Canqui H, Pelton MP, Suyker AE (2014) Biofuels from crop residue can reduce soil carbon and increase $\mathrm{CO}_{2}$ emissions. Nat Clim Chang 4(5):398.

23. Mars PA (1970) an inquiry into the feasibility of producing particle board from groundnut husks in India. An inquiry into the feasibility of producing particle board from groundnut husks in India. Trop. Prod. Inst., Abingdon, Berks, UK. TPI report, No. G-55 73pp.

24. Mendham DS, O'connell AM, Grove TS, Rance SJ (2003) Residue management effects on soil carbon and nutrient contents and growth of second rotation eucalypts. Forest Ecol Manage 181(3):357-372.

25. Nendel K, Claub B, Bottger U (1998) the preconditioning of biomass by briquetting technology and the influence on the combustion behaviour. In The $10^{\text {th }}$ European Conference on Biomass for Energy and industry.Wurzburg, Germany

26. Olafimihan, E. O., K. A. Adebiyi, and S. O. Jekayinfa. "Effect of temperature on the production of ethanol fuel from selected agricultural residues." International Journal of Mechanical Engineering (IJME) 4.6 (2015): 51-56. 
27. Pimentel LG, Weiler DA, Pedroso GM, Bayer C (2015) Soil $\mathrm{N}_{2} \mathrm{O}$ emissions following cover $\square$ crop residues application under two soil moisture conditions. J Soil Sci Plant Nutr 178(4):631-640.

28. Pittelkow CM, Liang X, Linquist BA, Van Groenigen KJ, Lee J, Lundy ME Van Kessel C (2015) Productivity limits and potentials of the principles of conservation agriculture. Nature 517(7534): 365.

29. Pourhashem G, Adler PR, McAloon AJ, Spatari S (2013) Cost and greenhouse gas emission tradeoffs of alternative uses of lignin for second generation ethanol. Environ Res Lett 8(2):025021.

30. Prasad R, Gangaiah B, Aipe KC (1999) Effect of crop residue management in a rice-wheat cropping system on growth and yield of crops and on soil fertility. Exp Agr 35(4):427-435.

31. Puget P, Lal R (2005) Soil organic carbon and nitrogen in a Mollisol in central Ohio as affected by tillage and land use. Soil Tillage Res 80(1-2):201-213.

32. Rani, K., et al. "Biological Treatment Of Distillery Waste Water-An Overviewll." International Journal of General Engineering and Technology 2.4 (2013): 15-24.

33. Rather, Nasir UlRasheed, and Sheen Moses. "Biomass Resource Assessment and Potential in India." International Journal of Civil, Structural, Environmental and Infrastructure Engineering Research and Development (IJCSEIERD) 8.1 (2018): 9-18.

34. Rocha JHT, de Moraes Gonçalves J L, Gava J L, de Oliveira Godinho T, Melo E A, Bazani JH, Wichert MP (2016) Forest residue maintenance increased the wood productivity of a Eucalyptus plantation over two short rotations. Forest Ecol Manag 379:1-10.

35. Saharawat Y S, Ladha JK, Pathak H, Gathala MK, Chaudhary N, Jat ML (2012) Simulation of resource-conserving technologies on productivity, income and greenhouse gas GHG emission in rice-wheat system. JSSEM 3(1): 9-22.

36. Signor D, Pissioni LLM, Cerri CEP (2014) Greenhouse gases emissions due to sugarcane trash on the soil. Bragantia 73(2):113-122.

37. Six J, Ogle SM, Jay Breidt F, Conant RT, Mosier AR, Paustian K (2004) The potential to mitigate global warming with no $\square$ tillage management is only realized when practised in the long term. Glob change biol 10(2):155-160.

38. Stavi I, Bel G, Zaady E (2016) Soil functions and ecosystem services in conventional, conservation, and integrated agricultural systems. A review. Agron Sustain Dev 36(2):32.

39. Tavares OCH, Lima E, Zonta E (2010) Sugarcane growth and productivity under different tillage and crop systems. Acta Sci Agron 32(1):61-68.

40. Tormena CA, Karlen DL, Logsdon S, Cherubin MR (2016) Visual soil structure effects of tillage and corn stover harvest in Iowa. Soil Sci Soc Am J 80(3):720-726.

41. Trivelin PCO, Franco HCJ, Otto R, Ferreira DA, Vitti AC, Fortes C, Cantarella H (2013) Impact of sugarcane trash on fertilizer requirements for Sao Paulo, Brazil. Sci Agric 70(5):345-352.

42. Valim WC, Panachuki E, Pavei DS, Sobrinho TA, Almeida WS (2016) Effect of sugarcane waste in the control of interrill erosion. Semin Cienc Agrar37 (3):1155-1164.

43. Whitbread A, Blair G, Konboon Y, Lefroy R, Naklang K (2003) Managing crop residues, fertilizers and leaf litters to improve soil $C$, nutrient balances, and the grain yield of rice and wheat cropping systems in Thailand and Australia. Agric Ecosyst Environ 100(2-3):251-263. 


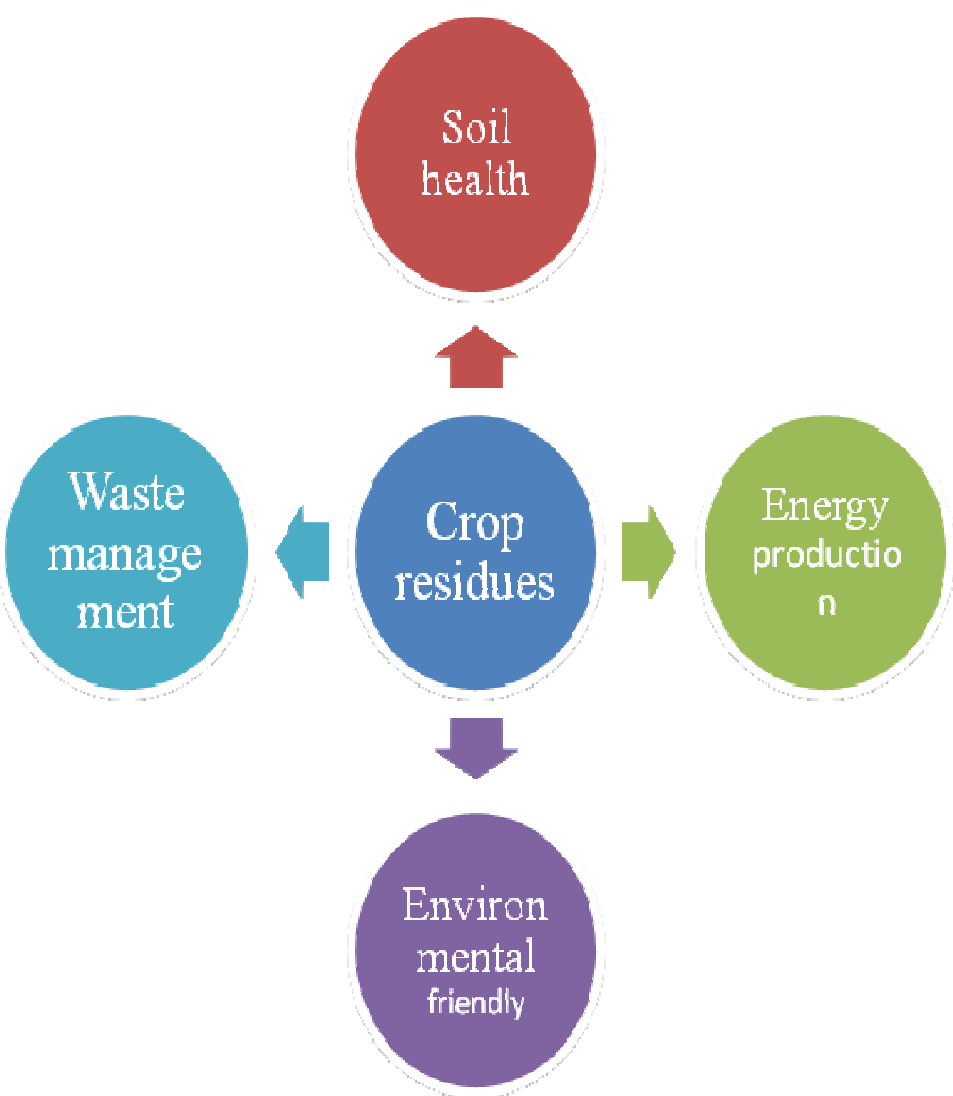

Figure 1: Crop Residues and their uses.

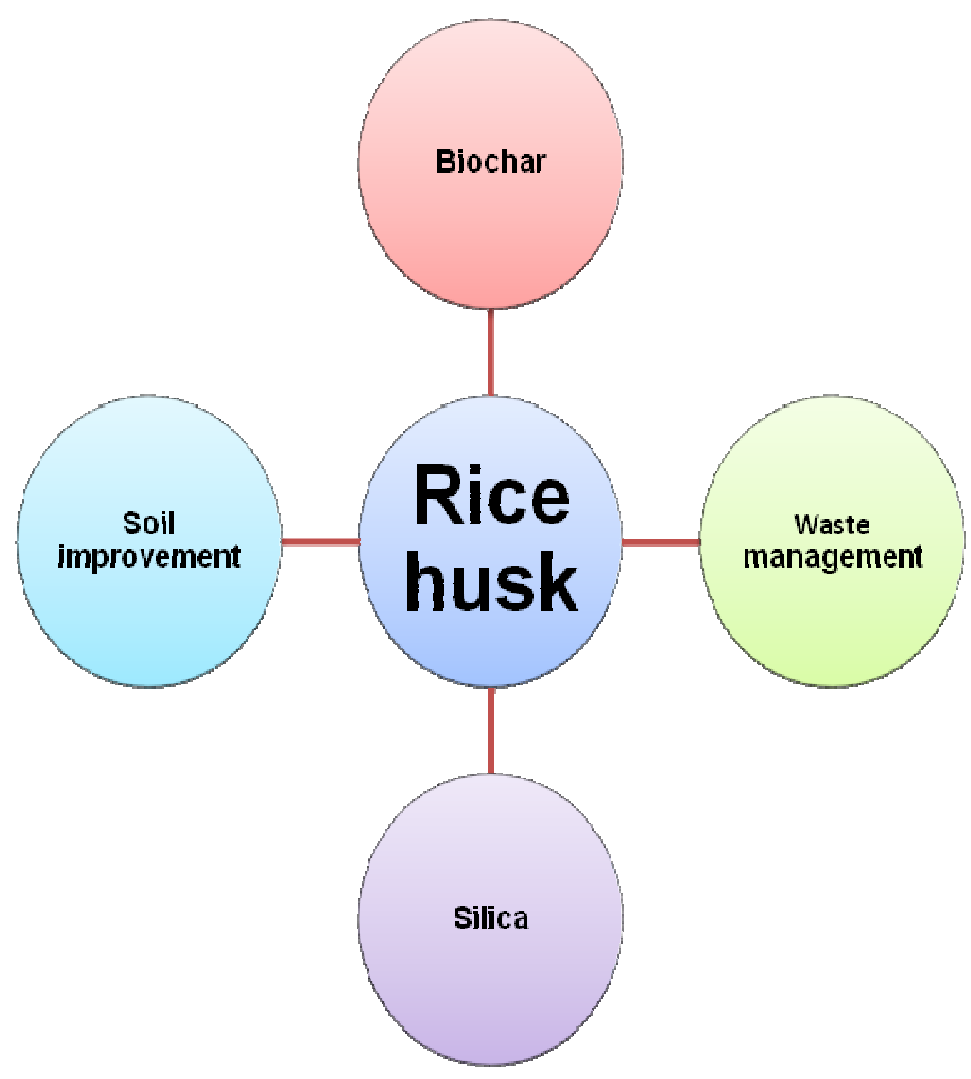

Figure 2: Uses of Rice Husk. 

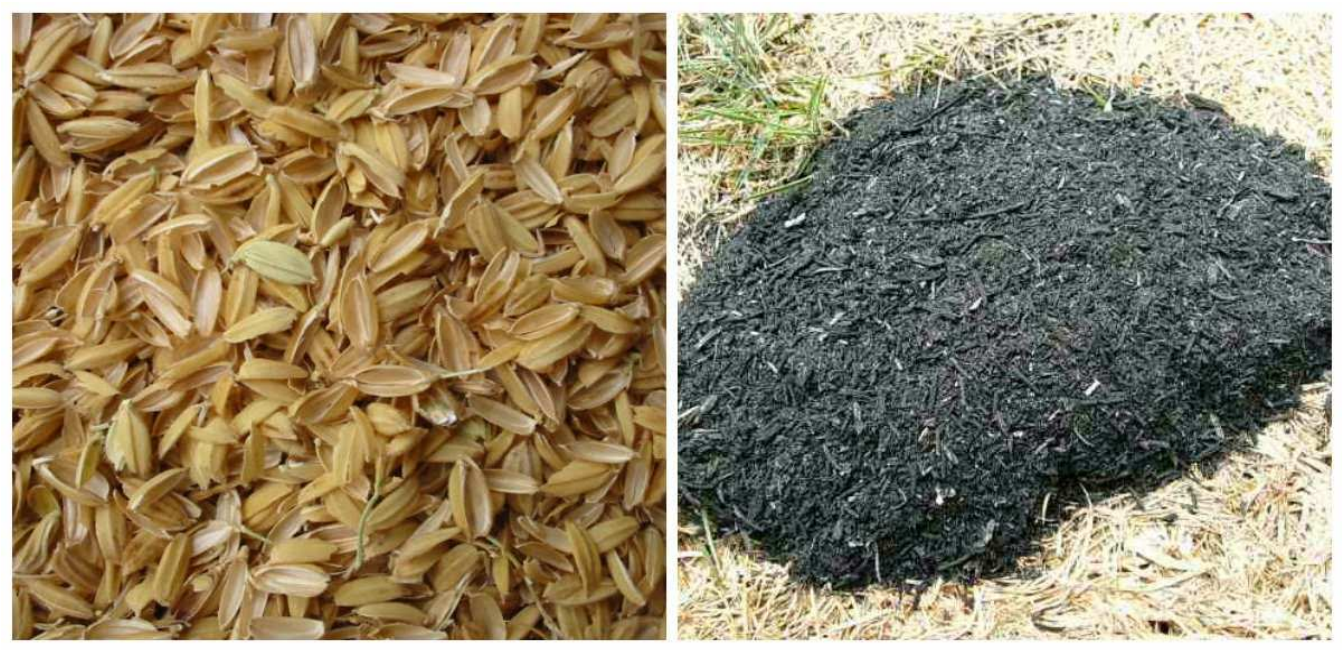

Figure 3: Biochar.

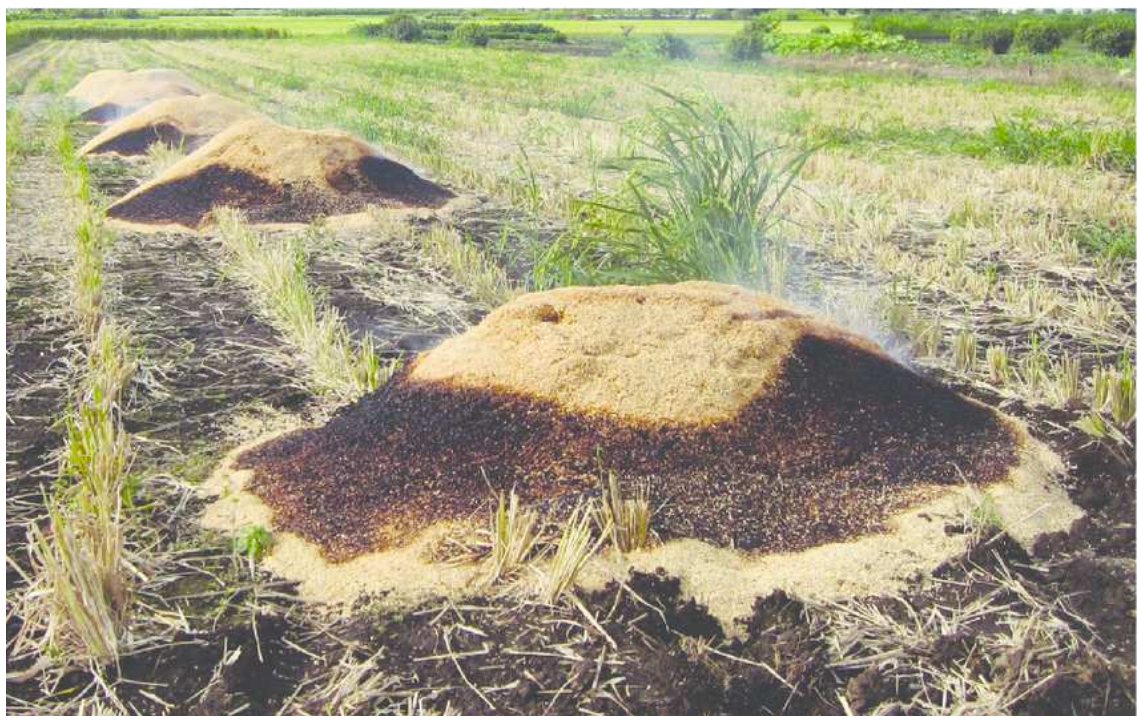

Figure 4: Burning of Crop Residues in Field.

Table 1: List of Crops used for Crop Residues

\begin{tabular}{|c|c|c|c|}
\hline Crops & Vernacular Names & Botanical Name & Family \\
\hline \multicolumn{4}{|c|}{ Cereals and Millets } \\
\hline Rice & Dhan, Chawal & Oryza sativa $\mathrm{L}$. & Poaceae \\
\hline Wheat & Gehun & Triticum aestivum $\mathbf{L}$. & Poaceae \\
\hline Maize & Corn, makka & Zea mays $\mathbf{L}$. & Poaceae \\
\hline Oats & Jau & Avena sativa $\mathbf{L}$. & Poaceae \\
\hline Rye & Rye & Secale cereale $\mathbf{L}$. & Poaceae \\
\hline Sorghum & Bajra & Sorghum bicolor (L.) Moench & Poaceae \\
\hline Barley & Jwar & Hordeum vulgare $\mathbf{L}$. & Poaceae \\
\hline \multicolumn{4}{|c|}{ Legumes } \\
\hline Beans & Green bean & Phaseolus vulgaris $\mathbf{L}$. & Paplionaceae \\
\hline Broad beans & Faba bean & Vicia faba $\mathbf{L}$. & Paplionaceae \\
\hline Chick peas & Garbanzo, Bengal bean & Cicer arietinum $\mathbf{L}$. & Paplionaceae \\
\hline Groundnut & Moongfali & Arachis hypogaea L. & Paplionaceae \\
\hline Lentils & Dal & Lens culinaris Medik. & Paplionaceae \\
\hline Peas & Matar & Pisum sativum $\mathbf{L}$. & Paplionaceae \\
\hline Soybeans & Bhat & Glycine max (L.) Merr. & Paplionaceae \\
\hline
\end{tabular}




\begin{tabular}{|l|l|l|l|}
\hline \multicolumn{5}{|c|}{ Oil Crops } \\
\hline Linseed & Flax & Linum usitatissimum L. & Linaceae \\
\hline Safflower & Kusum & Catharanthus roseus (L.) G.Don & Asteraceae \\
\hline Seed cotton & Kapas & Gossypium hirsutum L. & Malvaceae \\
\hline Sesame & Til & Sesamum indicum L. & Pedaliaceae \\
\hline Sunflower & Surajmukhi & Helianthus annuus L. & Asteraceae \\
\hline Rape seed & Oilseed rape & Brassica rapa L. & Brassicaceae \\
\hline \multicolumn{5}{|c|}{ Sugar Yielding } \\
\hline Sugarcane & Ganna & Saccharum officinarum L. & Poaceae \\
\hline Sugarbeet & Beet & Beta vulgaris L. & Amaranthaceae \\
\hline \multicolumn{5}{|l|}{ Tubers } & Solanaceae \\
\hline Potato & Aalu & Solanum tuberosum L. & Convolvulaceae \\
\hline Sweet potato & Sakarkand & Ipomoea batatas (L.) Lam. &
\end{tabular}

Table 2: Crop Residues Burnt in India

\begin{tabular}{|l|l|c|c|}
\hline \multicolumn{1}{|c|}{ Crop } & \multicolumn{1}{|c|}{$\begin{array}{c}\text { Major Producer States having } \\
\text { Surplus Crop Residue }\end{array}$} & $\begin{array}{c}\text { Amount of Crop } \\
\text { Residues(Million Tonne) }\end{array}$ & $\begin{array}{c}\text { Surplus Crop Residues } \\
\text { (Million Tonne) }\end{array}$ \\
\hline Rice & Punjab, Haryana & 18.6 & 15.0 \\
\hline Wheat & Punjab, Haryana, UP, Rajasthan, M.P. & 67.6 & 15.4 \\
\hline Sugarcane & $\begin{array}{l}\text { UP, Maharashtra, Karnataka, Tamil } \\
\text { Nadu, Andhra Pradesh, Gujarat }\end{array}$ & 26.9 & 21.6 \\
\hline *Percentage given in parenthesis (SPRERI, 2004)
\end{tabular}

